\title{
Effects of Agricultural Practices on Carbon Emission and Soil Health
}

\section{Marija Galic ${ }^{* 1}$, Darija Bilandzija ${ }^{2}$, Aleksandra Percin ${ }^{3}$, Ivana Sestak ${ }^{4}$, Milan Mesic $^{5}$, Mihaela Blazinkov ${ }^{6}$, Zeljka Zgorelec ${ }^{7}$}

${ }^{1}$ Department of General Agronomy, Faculty of Agriculture, University of Zagreb, Svetosimunska street 25, 10000 Zagreb, Croatia

e-mail: mcacic@agr.hr

${ }^{2}$ Department of General Agronomy, Faculty of Agriculture, University of Zagreb, Svetosimunska street 25, 10000 Zagreb, Croatia e-mail: dbilandzija@agr.hr

${ }^{3}$ Department of General Agronomy, Faculty of Agriculture, University of Zagreb, Svetosimunska street 25, 10000 Zagreb, Croatia

e-mail: apercin@agr.hr

${ }^{4}$ Department of General Agronomy, Faculty of Agriculture, University of Zagreb, Svetosimunska street 25, 10000 Zagreb, Croatia e-mail: isestak@agr.hr

${ }^{5}$ Department of General Agronomy, Faculty of Agriculture, University of Zagreb, Svetosimunska street 25, 10000 Zagreb, Croatia e-mail: mmesic@agr.hr

${ }^{6}$ College of Slavonski Brod, dr. Mile Budaka 1, 35000 Slavonski Brod, Croatia

e-mail: Mihaela.Blazinkov@vusb.hr

${ }^{7}$ Department of General Agronomy, Faculty of Agriculture, University of Zagreb, Svetosimunska street 25, 10000 Zagreb, Croatia

e-mail: zzgorelec@agr.hr

Cite as: Galic, M., Bilandzija, D., Percin, A., Sestak, I., Mesic, M., Blazinkov, M., Zgorelec, Z., Effects of Agricultural Practices on Carbon Emission and Soil Health, J. sustain. dev. energy water environ. syst., 7(3), pp 539-552, 2019, DOI: https://doi.org/10.13044/j.sdewes.d7.0271

\section{ABSTRACT}

The agricultural sector is a source of greenhouse gas emissions that directly affect the global problem of climate change and contribute approximately $11 \%$ in total greenhouse gas emissions in the world and in Croatia too. Irregular and irresponsible agricultural practices, such as excessive tillage and improper fertilization often lead to soil carbon loss and increased carbon dioxide emissions to the atmosphere. This field study provides results how agricultural practices affect carbon dioxide emissions from soil, carbon sequestration and soil quality during the cultivation of winter wheat. The field experiment was conducted in a temperate continental climate on distric Stagnosol. Four investigated treatments were: organic fertilization, mineral fertilization, control treatment and black fallow. The lowest carbon dioxide emission was recorded on bare soil and the highest on organic fertilization treatment. The application of manure, mineral fertilizers and calcification rendered significant effect on some soil chemical characteristics and daily carbon dioxide flux.

\section{KEYWORDS}

Soil respiration, Yield, Soil flux, Mineral and organic fertilization, Soil quality.

\footnotetext{
${ }^{*}$ Corresponding author
} 


\section{INTRODUCTION}

The influence of the agricultural ecosystems can have a significant role in the production and consumption of Greenhouse Gases (GHGs) that directly affect the global problem of climate change [1]. Among GHGs, carbon dioxide $\left(\mathrm{CO}_{2}\right)$ is one of the most significant contributors to regional and global warming [2]. The agricultural soils can act as a source or a sink of GHGs [3]. Therefore, one part of $\mathrm{CO}_{2}$ is released from soil in the process of soil respiration. Soil respiration or soil $\mathrm{CO}_{2}$ flux is one of the most important components of the ecosystem carbon budget, which consists of organic matter decomposition and mineralization, root respiration and rhizosphere or faunal respiration [4]. $25 \%$ of the total carbon exchange between the atmosphere and terrestrial sources is ascribed to annual global soil emission [5]. Numerous studies have shown that many factors such as excessive tillage and irrigation practices, application of large amounts of fertilizers, soil aeration and microbial processes lead to higher soil flux $\left(\mathrm{C}-\mathrm{CO}_{2}\right)$ emissions into the atmosphere and depletion of carbon (organic matter) content in soil [6]. Also, the production of $\mathrm{CO}_{2}$ in the soil is strongly correlated with soil temperature and soil moisture [7]. When soil temperature increases, organic matter decomposition, oxidation, microbial activity and $\mathrm{C}$ mineralization processes accelerate which leads to increased $\mathrm{C}-\mathrm{CO}_{2}$ emission from the soil [8]. Soil temperature represents an important factor in controlling major processes in the $\mathrm{C}$ cycle [2]. Soil moisture also affects $\mathrm{CO}_{2}$ production, distribution and microbial activity [9]. As is known, the application of mineral fertilizer and manure has similar and very large effects on soil fertility. Nitrogen fertilization is one of the commonly used agronomic practices used in conventional and integrated cropping systems to greatly improve plant productivity [10]. Some studies show that nitrogen application resulted in a reduction of both emission rate and season-long cumulative emission of $\mathrm{C}-\mathrm{CO}_{2}$ from soil [11] while other studies show that fertilization has no direct effect on soil carbon sequestration [12]. Therefore, optimal C:N ratio has high importance in sustainable soil management [13].

Regarding that soil formation is an extremely slow process, it could be considered as a non-renewable resource. Climate changes and its consequences not only affect humans but also affect soil possibility to provide its Ecosystem services in the future. It is very important that soil is a major factor in our fight against climate change, as the third largest carbon base after oceans and sedimentary rocks. The Republic of Croatia as a signatory of the UNFCCC Convention has the obligation to write a National Inventory Report (NIR) using the Intergovernmental Panel on Climate Change (IPCC) and Land Use, Land Use Change and Forestry (LULUCF) guidelines. The Government of the Republic of Croatia produced several National Reports from the Republic of Croatia according to the UNFCCC where different universal coefficients for GHGs calculations were used, so the primary research goal was obtaining our own national data. According to the Kyoto Protocol, the EU has taken a leading role in tackling climate change and set the goal of reducing GHG emissions by $80 \%$ by 2050 where the Republic of Croatia shows the possibility to achieve the European goal of reducing GHGs. Although many studies on soil $\mathrm{CO}_{2}$ emissions are conducted around the world, world literature provides insight into the contradictory results obtained with regard to the location of measurement, soil type, climate, land use and management, etc. Due to the lack of research and our own national data related to the topics of soil respiration, the goal was to obtain and have a real data of GHGs from agricultural soils in the real agro-climatic conditions of Western Pannonian agricultural subregion. Also, the main objectives of this research were to determine the effects of mineral and organic fertilization in winter wheat (Triticum aestivum L.) vegetation and agro-ecological factors on $\mathrm{C}-\mathrm{CO}_{2}$ emissions and $\mathrm{C}$ sequestration from distric Stagnosol and to determine the influence on soil quality [pH, Electro-Conductivity (EC), Organic Matter (OM), Available Phosphorus (AP), Available Potassium (AK), Total Nitrogen (TN) and total number of bacteria and fungi]. 


\section{MATERIALS AND METHODS}

The field experiment with four different treatments was set up in central part of Croatia in Popovaca (N 45 33' 21.42", E $\left.16^{\circ} 31^{\prime} 44.62^{\prime \prime}\right)$. It was initiated in 1996 with the aim of establishing optimal fertilization in existing conditions that would have a positive effect on yield and would not adversely affect the environment (water), and later (2011), it was expanded to the research on soil C- $\mathrm{CO}_{2}$ flux measurements. The cover crop at the experimental field in the investigated year (2016) was winter wheat (Triticum aestivum L. - Srpanjka variety) which was sown on $12^{\text {th }}$ November 2015 and harvested on $9^{\text {th }}$ July 2016. The winter wheat yield was determined by gravimetric method [14]. The soil type was classified as plain, deep, distric drained pseudogley (Stagnosol) [15] and as distric Stagnosols [16]. The dimension of each trial treatment was $30 \times 130 \mathrm{~m}^{2}$ including blank space. The distance between treatments was $2 \mathrm{~m}$ by each side, as well as between 4 replicates. The fertilization with phosphorus $(\mathrm{P})$ and potassium $(\mathrm{K})$ was uniform for II and III treatments (120 kg ha ${ }^{-1}$ for P and $180 \mathrm{~kg} \mathrm{ha}^{-1}$ for K). On $15^{\text {th }}$ November 2015, soil ploughing and preparation (25-30 cm depth), basic fertilization with NPK $=7: 20: 30$ for winter wheat $[30 \%$ nitrogen $(\mathrm{N})+100 \% \mathrm{~K}$ and $100 \% \mathrm{P}]$ and winter wheat sowing are done. The nitrogen replenishment was carried out on two dates, first on $11^{\text {th }}$ March 2016 in an amount of $25 \% \mathrm{~N}$ and the second on $4^{\text {th }}$ April 2016 in the amount of $45 \% \mathrm{~N}(25 \%+$ $20 \%$ ) using KAN. Harvest of winter wheat was on $9^{\text {th }}$ July 2016. Four investigated treatments were:

- (C) Control treatment - no fertilization;

- (OF) Organic Fertilization $-40 \mathrm{t} \mathrm{ha}^{-1}$ of solid farmyard mixed manure $+\mathrm{P}+\mathrm{K}$;

- (MF) Mineral Fertilization $-300 \mathrm{~kg} \mathrm{ha}^{-1} \mathrm{~N}+\mathrm{P}+\mathrm{K}$;

- (BF) Black Fallow - no vegetation.

\section{Soil sampling and analysis}

Soil sampling for chemical and microbiological analysis was conducted twice during 2016 (in April - stem extension phase and in June - grain formation phase) in winter wheat vegetation period at the depth of $0-30 \mathrm{~cm}$. Average soil samples made from four replications on each treatment were taken and air dried, milled, sieved $(<2 \mathrm{~mm})$ and homogenized according to the HRN ISO11464 [17] protocol. $\mathrm{pH}$ was determined by potentiometric measurement in accordance with modified HRN ISO 10390 [18] (1:2.5 suspension of soil in $1 \mathrm{~mol} \mathrm{~L}^{-1} \mathrm{KCl}$ ). The content of $\mathrm{OM}$ was determined with a wet combustion method (sulfochromic oxidation method) [19]. The AP and AK were extracted by ammonium lactate (AL) solution [20] and detected by spectrophotometric and flame photometric methods, respectively [21]. TN in soil was determined by dry combustion method [22]. Soil EC was determined according to the [23]. Samples for microbiological analysis were analysed immediately after sampling in the natural state of soil moisture. The total number of fungi and bacteria was determined by the dilution method [24].

\section{Climate conditions at the experimental site}

For the interpretation of climatic conditions at the experimental site in the reference period 1961-1990 and studied period November 2015-November 2016, the official meteorological data from the main meteorological station of Meteorological and Hydrological Service of Croatia located in Sisak were used [25]. The climate conditions at the experimental site are described by Lang's rain factor and Walter climate diagram. Lang's rain factor was calculated by dividing the annual precipitation (in $\mathrm{mm}$ ) by the mean temperature (in ${ }^{\circ} \mathrm{C}$ ) [26]. The climate classification for the interpretation of Lang's rain factor is conducted according to Gracanin's climate classification [27]. Walter climate diagram represents a relationship between the average monthly air temperature 
and rainfall during long-term measurement which provides a summary of a local climate [28].

The soil water balance was calculated according to Thornthwaite's method where potential evapotranspiration, actual evapotranspiration, water deficit and water surplus were determined. Thornthwaite's method is basically an empirical relationship between mean monthly potential evapotranspiration and means monthly temperature, wherein uniform values of wind and humidity have been assumed [29].

\section{Carbon dioxide emission measurement and agro-ecological factors}

The measurements of soil $\mathrm{CO}_{2}$ concentrations and agro-climatic conditions were conducted 10 times during the vegetation year (2015/2016) in the following months: November, December, April, May, June, July $2 \times$, August, September and November in three repetitions on all treatments. The most common methods used to measure soil fluxes are chamber systems [30]. In this research, the soil $\mathrm{CO}_{2}$ concentrations were also measured by a closed static chamber method, as described in Bilandzija et al. [2]. Initial $\mathrm{CO}_{2}$ concentrations were measured before the chamber was closed. The incubation time was 30 minutes after which $\mathrm{CO}_{2}$ concentrations were measured. In situ $\mathrm{CO}_{2}$ concentration measurements (ppm) were carried out by a portable infrared $\mathrm{CO}_{2}$ detector (GasAlertMicro5 IR, 2011). The soil $\mathrm{CO}_{2}$ efflux was calculated from the increase in $\mathrm{CO}_{2}$ concentration over time [30].

Because $\mathrm{CO}_{2}$ emissions from the soil are indirectly influenced by moisture content and air temperature, reliable data on agro-ecological conditions are required [31]. Thus, seasonal changes in $\mathrm{CO}_{2}$ flux have been reported to follow seasonal temperature trends [32]. Therefore, during each measurement, air temperature $\left[{ }^{\circ} \mathrm{C}\right]$, relative air humidity [\%] and air pressure $[\mathrm{hPa}]$ were measured with appropriate instruments (Testo 511 and Testo 610, 2011). In addition, soil temperature $\left[{ }^{\circ} \mathrm{C}\right]$, soil moisture [\%] and electroconductivity $[\mathrm{mS} / \mathrm{m}$ ] were measured with an instrument (IMKO HD2 - probe Trime, Pico64, 2011) at $10 \mathrm{~cm}$ depth near each chamber. Table 1 presents the mentioned instruments with accuracy.

Table 1. Accuracy of instruments

\begin{tabular}{ccc}
\hline Instrument & Function & Accuracy \\
\hline GasAlertMicro 5 IR & $\mathrm{CO}_{2}$ concentration $[\mathrm{ppm}]$ & $\pm 0.2 \%$ \\
\hline Testo 511 & Air pressure $[\mathrm{hPa}]$ & \pm 3 \\
\hline \multirow{2}{*}{ Testo 610 } & Air temperature $\left[{ }^{\circ} \mathrm{C}\right]$ & \pm 0.5 \\
& Relative air humidity $[\%]$ & \pm 2.5 \\
\hline \multirow{2}{*}{ IMKO HD 2 } & Soil temperature $\left[{ }^{\circ} \mathrm{C}\right]$ & \pm 0.2 \\
& Soil moisture $[\%]$ & \pm 0.3 \\
& Electro-conductivity $[\mathrm{mS} / \mathrm{m}]$ & $\pm 0.2 \%$ \\
\hline
\end{tabular}

\section{Data analysis and statistics}

Statistical analyses of differences in winter wheat yield according to fertilization treatments were computed by analysis of variance (ANOVA) (SAS 9.1, SAS Institute Inc., USA). The significance test was performed at a probability level of $p<0.05$. Also, using analysis of variance differences in soil chemical (pH, EC, OM, TN, AP and AK) and microbiological (total number of fungi and bacteria) properties among treatment means were tested for each sampling time and across the sampling dates for each treatment. Statistical analyses of differences in daily $\mathrm{C}-\mathrm{CO}_{2}$ fluxes according to fertilization treatments and black fallow treatment were performed for each of ten measurement months period from November 2015-November 2016. In the end, according to fertilizer treatments comparison of mean annual $\mathrm{C}-\mathrm{CO}_{2}$ flux values and soil chemical parameters was analysed also by ANOVA, while all differences among 
treatment means and sampling dates means were separated using Fisher's least significant difference procedure.

\section{RESULTS AND DISCUSSION}

Mean annual amount of precipitation in Sisak during the 30-year reference period was $865 \mathrm{~mm}$. The real evapotranspiration was $655.1 \mathrm{~mm}$ per year. Mean annual temperature was $10.6{ }^{\circ} \mathrm{C}$ indicating temperate continental climate. According to Lang's rain factor $(L f)$, the reference period was characterised by a humid climate $(L f=82)$ [27]. The investigated 2016 was more humid $(+159 \mathrm{~mm})$ and warmer $\left(+1.5^{\circ} \mathrm{C}\right)$ compared to reference period with mean annual precipitation amount of $1,024 \mathrm{~mm}$ and mean annual temperature of $12.1^{\circ} \mathrm{C}$. According to Lang's rain factor, the year 2016 was characterised by a humid climate $(L f=85)$.

According to Walter's climate diagram, the average climatic conditions show no record of dry periods during the reference period (Figure 1), while in the studied year (2016) a water deficit in July, August and September was recorded (Figure 2). The real evapotranspiration in 2016 was higher by $30 \mathrm{~mm}$ than in the reference period. Water deficit in the soil in 2016 occurred in the same months as in the reference period, but in a larger quantity $(+23.6 \mathrm{~mm})$. The same applies to water surplus $(+128.8 \mathrm{~mm})$ (Figure 3 and Figure 4).

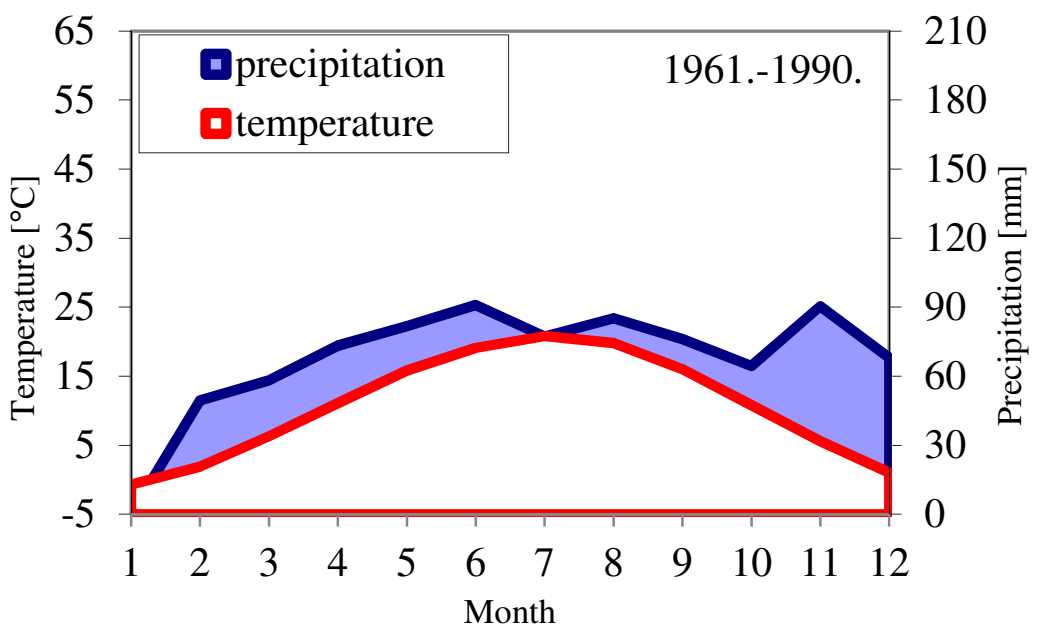

Figure 1. Walter climate diagram for the reference period

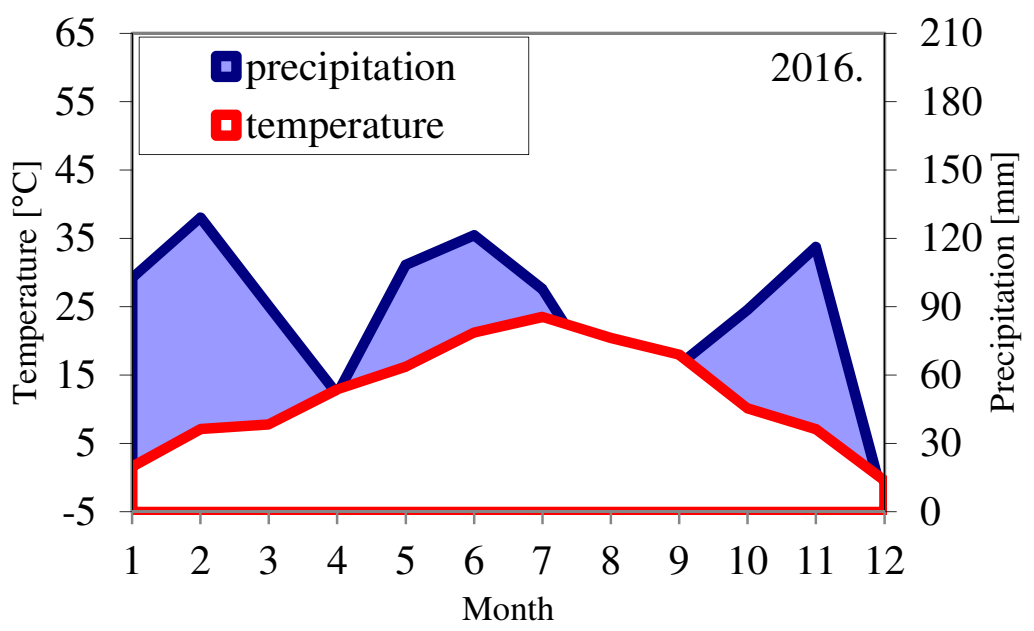

Figure 2. Walter climate diagram for the investigated 2016 


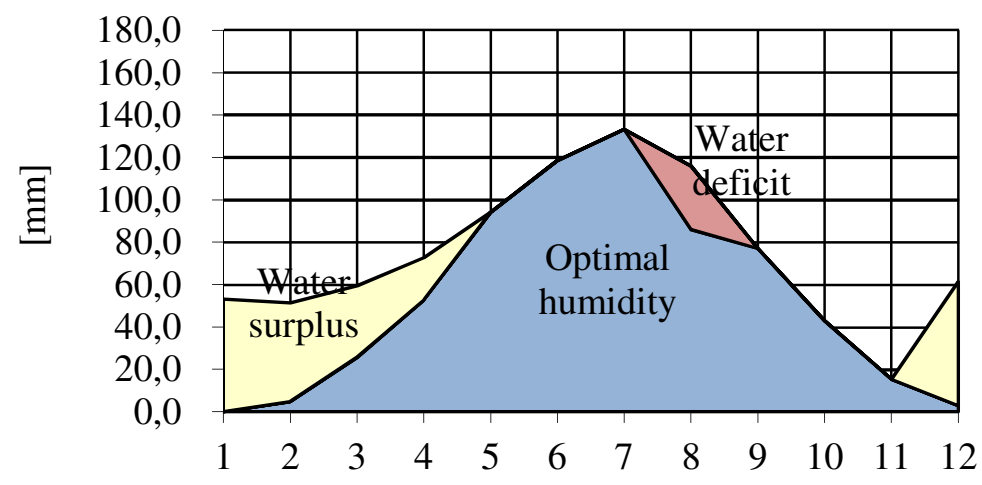

Months

Figure 3. Water balance in the soil according to Thornthwaite method for the reference period (1961-1990)

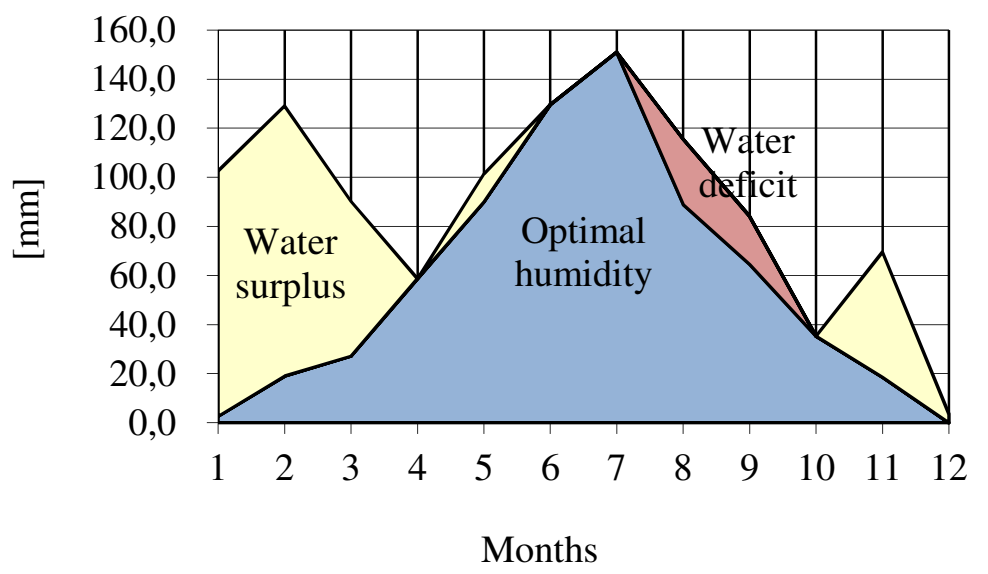

Figure 4. Water balance in the soil according to Thornthwaite method for the investigated 2016

\section{Crop yield, soil chemical and microbiological properties}

Figure 5 shows winter wheat yield according to the investigated treatments. The yield observed in MF (7.37 t ha-1) and OF (7.07 t ha $\mathrm{ta}^{-1}$ ) was significantly higher than the yield observed in the control treatment $\left(1.12 \mathrm{tha}^{-1}\right)$. The yield determined between MF and OF treatment was not significantly different (Figure 5). Until 2014, when organic fertilization was applied, mineral fertilization was also applied on OF treatment $(250 \mathrm{~N}+$ $\mathrm{P}+\mathrm{K}$ ) so no significant differences between yield at OF and MF treatments could be partly explained due to the high nutrient accumulation in the soil. Accordingly, several authors have shown nitrogen as the most important element to achieve stable high grain yields [33] and improving grain quality [34]. Similarly, the present experiment confirmed a tendency of increased yield after mineral nitrogen application in comparison with organic fertilization [35]. In organic treatments, lower yields were observed in the first two years, but after third-year yields did not differ [36].

Table 2 presents soil chemical properties in dependence of fertilization treatments and sampling time. The $\mathrm{pH}$ ranged from 4.93 in the stem extension phase to 6.22 in grain formation phase. The EC values were very low and ranged from 9.3 to $10.7 \mathrm{mS} \mathrm{m}^{-1}$. The mean $\mathrm{pH}$ and $\mathrm{EC}$ were not significantly different between treatments. The content of $\mathrm{OM}$ in soil ranged from $1.4 \%$ in control treatment to $2.9 \%$ in OF. The content of OM was significantly higher in $\mathrm{OF}$ and $\mathrm{MF}$ treatment than in $\mathrm{C}$ and $\mathrm{BF}$. The AP ranged from $73 \mathrm{mg} \mathrm{kg}^{-1}$ (BF) to $197 \mathrm{mg} \mathrm{kg}^{-1}$ (MF) and $\mathrm{AK}$ from $147 \mathrm{mg} \mathrm{kg}^{-1}$ (BF) to $301 \mathrm{mg} \mathrm{kg}^{-1}$ (OF). The TN ranged from $0.98 \mathrm{~g} \mathrm{~kg}^{-1}$ in control treatment to $1.68 \mathrm{~g} \mathrm{~kg}^{-1}$ in MF. Average 
values of $\mathrm{AP}, \mathrm{AK}$ and $\mathrm{TN}$ were significantly higher on $\mathrm{OF}$ and $\mathrm{MF}$ than on treatments without fertilization $(\mathrm{C}$ and $\mathrm{BF})$. When comparing the first (stem extension phase) and the second (grain formation phase) sampling, the significant difference can be seen in EC between all treatments, for AP only between $\mathrm{BF}$ treatments and for $\mathrm{TN}$ only between control treatments.

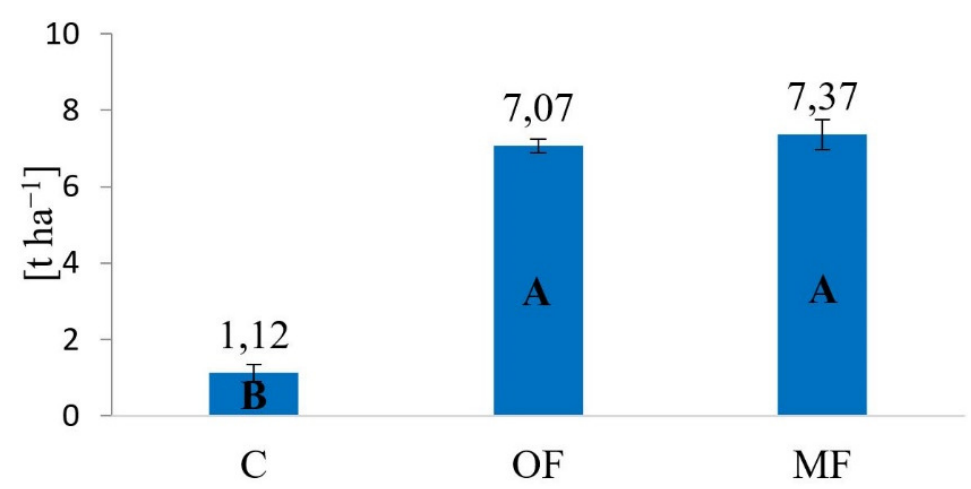

Figure 5. Winter wheat yield according to the investigated treatments [mean values marked with the same letter are not significantly different (SAS 9.1, $p<0.05$ )]

Table 2. Soil chemical properties according to the fertilization treatment and sampling time ( $n=4$ : in the first and the second soil sampling, the composed sample made from four replications for each treatment are made and analysed)

\begin{tabular}{ccccccc}
\hline \multicolumn{7}{c}{ First soil sampling (stem extension phase) - April 2016 } \\
\hline Treatment & $\mathrm{pH} \mathrm{1:2.5} \mathrm{KCl}$ & $\mathrm{EC} 1: 5\left[\mathrm{mS} \mathrm{m}^{-1}\right]$ & $\mathrm{OM}[\%]$ & $\mathrm{AP}\left[\mathrm{mg} \mathrm{kg}^{-1}\right]$ & $\mathrm{AK}\left[\mathrm{mg} \mathrm{k}^{-1}\right]$ & $\mathrm{TN}\left[\mathrm{g} \mathrm{kg}^{-1}\right]$ \\
\hline $\mathrm{C}$ & $5.62 \mathrm{Aa}$ & $10.7 \mathrm{Aa}$ & $1.4 \mathrm{Ba}$ & $110 \mathrm{Ba}$ & $154 \mathrm{Ba}$ & $0.98 \mathrm{Bb}$ \\
$\mathrm{OF}$ & $5.22 \mathrm{Aa}$ & $10.7 \mathrm{Aa}$ & $2.7 \mathrm{Aa}$ & $196 \mathrm{Aa}$ & $299 \mathrm{Aa}$ & $1.60 \mathrm{Aa}$ \\
$\mathrm{MF}$ & $4.93 \mathrm{Aa}$ & $10.7 \mathrm{Aa}$ & $2.7 \mathrm{Aa}$ & $197 \mathrm{Aa}$ & $256 \mathrm{Aa}$ & $1.68 \mathrm{Aa}$ \\
$\mathrm{BF}$ & $5.16 \mathrm{Aa}$ & $10.7 \mathrm{Aa}$ & $2.3 \mathrm{Aa}$ & $101 \mathrm{Ba}$ & $147 \mathrm{Ba}$ & $1.43 \mathrm{Aa}$ \\
\hline \multicolumn{7}{c}{ Second soil sampling (grain formation phase) - June 2016} \\
\hline $\mathrm{C}$ & $6.22 \mathrm{Aa}$ & $9.4 \mathrm{Ab}$ & $1.4 \mathrm{Ca}$ & $88 \mathrm{Ba}$ & $149 \mathrm{Ba}$ & $1.12 \mathrm{Ca}$ \\
$\mathrm{OF}$ & $5.15 \mathrm{Aa}$ & $9.4 \mathrm{Ab}$ & $2.9 \mathrm{Aa}$ & $187 \mathrm{Aa}$ & $301 \mathrm{Aa}$ & $1.52 \mathrm{Aa}$ \\
$\mathrm{MF}$ & $5.49 \mathrm{Aa}$ & $9.3 \mathrm{Ab}$ & $2.8 \mathrm{Aa}$ & $192 \mathrm{Aa}$ & $296 \mathrm{Aa}$ & $1.43 \mathrm{ABa}$ \\
$\mathrm{BF}$ & $5.44 \mathrm{Aa}$ & $9.3 \mathrm{Ab}$ & $2.1 \mathrm{Ba}$ & $73 \mathrm{Bb}$ & $170 \mathrm{Ba}$ & $1.24 \mathrm{BCa}$ \\
\hline
\end{tabular}

Mean values marked with the same capital letters in the same time of sampling are not significantly different. Mean values marked with the same small letters between different time of sampling are not significantly different (SAS $9.1, p<0.05)$

The growth of microbial populations and their action in soils are dependent on the interaction between plant species and soil [37]. It is considered that 80 to $90 \%$ of soil processes are influenced by microorganisms [38] where bacteria and fungi can carry out almost all known biological reactions. Determination of the total number of bacteria and fungi in soils is one of the main indicators of soil biogenity [13].

In this research, the results showed that a low microbial number is prevalent. Total number of bacteria (Figure 6) ranged from $6.9 \times 10^{6} \mathrm{CFU} \mathrm{g}^{-1}$ on $\mathrm{BF}$ to $18.1 \times 10^{6}$ $\mathrm{CFU} \mathrm{g}^{-1}$ soil in OF depending on the sampling time and treatment. Total number of fungi (Figure 7) ranged from $6.5 \times 10^{4} \mathrm{CFU} \mathrm{g}^{-1}$ on $\mathrm{BF}$ to $18.9 \times 10^{4} \mathrm{CFU} \mathrm{g}^{-1}$ in OF. Looking at the first (stem extension phase) and the second (grain formation phase) soil sampling, it can be seen that bacteria number increased in all treatments in second sampling but showed significant difference only in $\mathrm{C}$ and $\mathrm{BF}$ treatments. The total number of fungi decreased in MF and BF treatments. BF treatment showed a significant difference of the total number of fungi in a relation to $\mathrm{C}$ and $\mathrm{OF}$ treatments in the second sampling. Between different times of sampling, significant difference was recorded only in OF treatment (Figure 7). These results are consistent with authors' cognition that bacteria and fungi responded differently to the organic and mineral fertilizers [39]. 


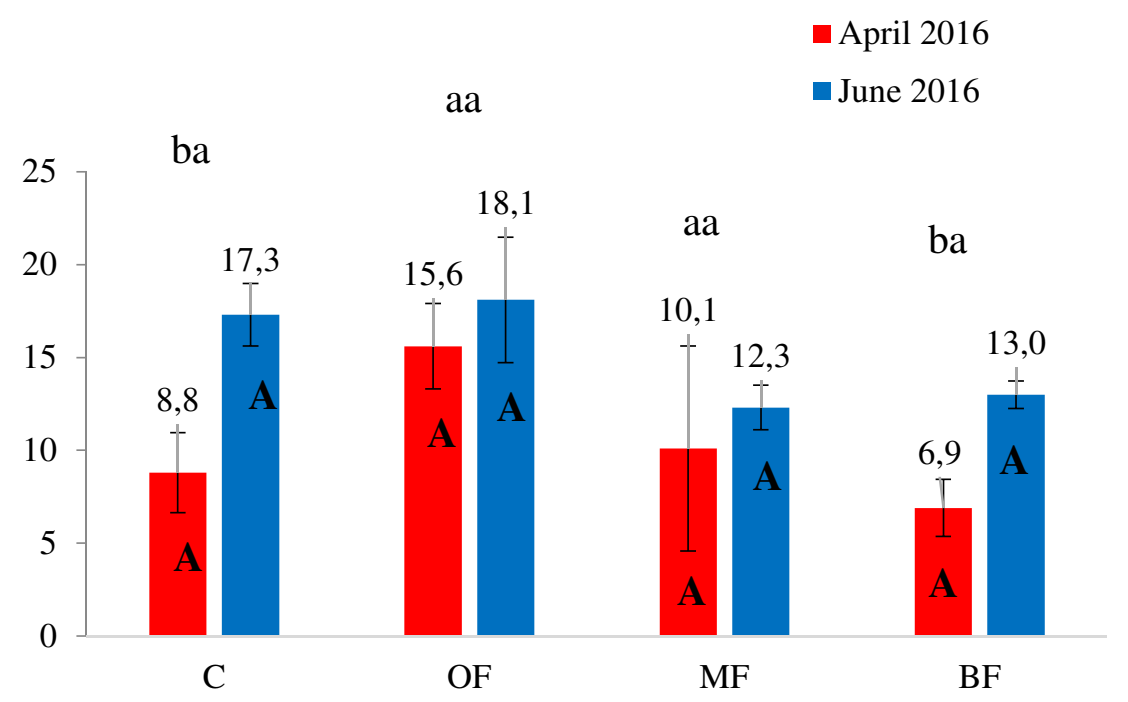

Figure 6. Total number of bacteria $\left(\times 10^{6} \mathrm{CFU} \mathrm{g}{ }^{-1}\right)$ in the first and the second sampling [mean values marked with the same capital letters in the same time of sampling are not significantly different, mean values marked with the same small letters between different time of sampling are not significantly different (SAS 9.1, $p<0.05)]$

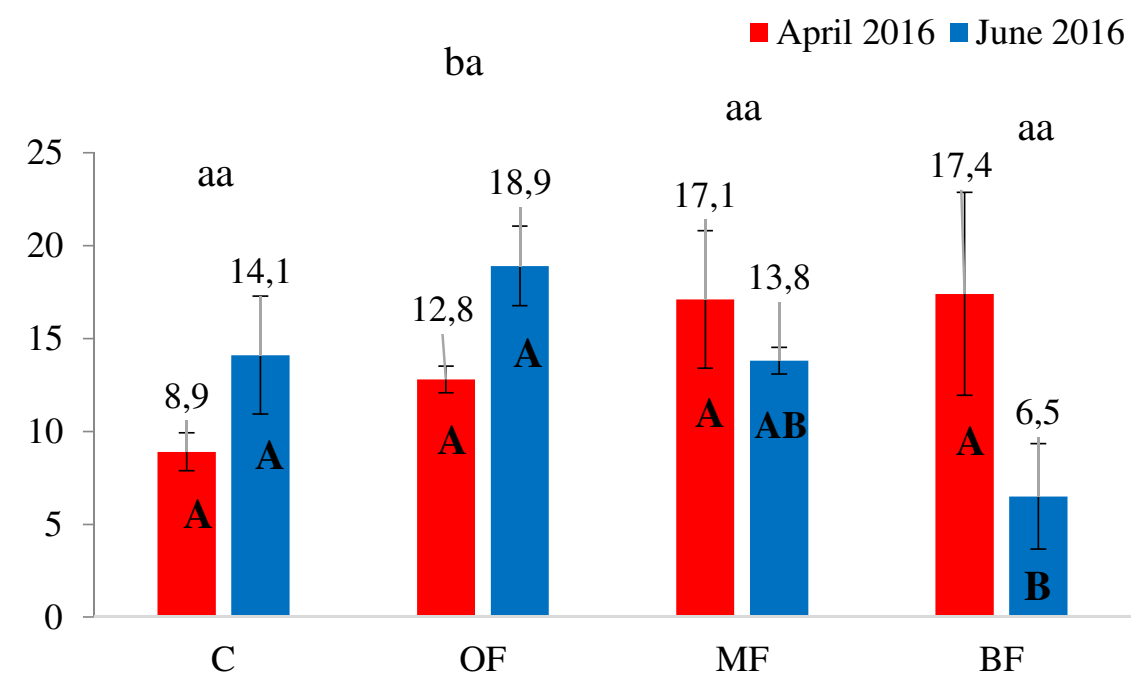

Figure 7. Total number of fungi $\left(\times 10^{4} \mathrm{CFU} \mathrm{g}{ }^{-1}\right)$ in the first and the second sampling [mean values marked with the same capital letters in the same time of sampling are not significantly different, mean values marked with the same small letters between different time of sampling are not significantly different (SAS 9.1, $p<0.05$ )]

\section{Agroclimatic factors and carbon dioxide flux}

A lot of research has been done to study the relationship between $\mathrm{C}-\mathrm{CO}_{2}$ flux and soil temperature or soil moisture. In this research, during the winter wheat growing season, average daily soil temperature ranged from $17.6{ }^{\circ} \mathrm{C}$ in November to $37.6{ }^{\circ} \mathrm{C}$ in August (Figure 8). In Moore and Dalva [40] research, C-CO emissions at $23{ }^{\circ} \mathrm{C}$ was 2.4 times higher than at $10{ }^{\circ} \mathrm{C}$ and showed a positive, linear correlation with the water content of the soil. In this research, $\mathrm{C}-\mathrm{CO}_{2}$ emission was 5.5 times higher at $\mathrm{BF}$ treatment without any influence of vegetation, at a soil temperature of $33.4{ }^{\circ} \mathrm{C}$ (June) than at $17.6{ }^{\circ} \mathrm{C}$ (November), thus confirming the high functional flux dependence on soil temperature and moisture (Figure 8 and Figure 9). A high positive correlation between $\mathrm{CO}_{2}$ emission rate and soil temperature was found for many soils under natural and agricultural conditions. Accordingly, to evaluate the effects of interannual variations in climate on 
global soil-to-atmosphere $\mathrm{CO}_{2}$ fluxes, from long-term study the authors concluded that annual soil- $\mathrm{CO}_{2}$ fluxes correlated with mean annual temperature [41]. The soil moisture affects soil $\mathrm{C}-\mathrm{CO}_{2}$ flux by its direct influence on root and microbial activities, or indirect influences on soil physical and chemical properties [42]. Authors found increased rates of day and night soil respiration when soil water content increased due to rainfall [43]. In this research, the soil moisture ranged from $19.7 \%$ in November to $34.1 \%$ in July (Figure 8).

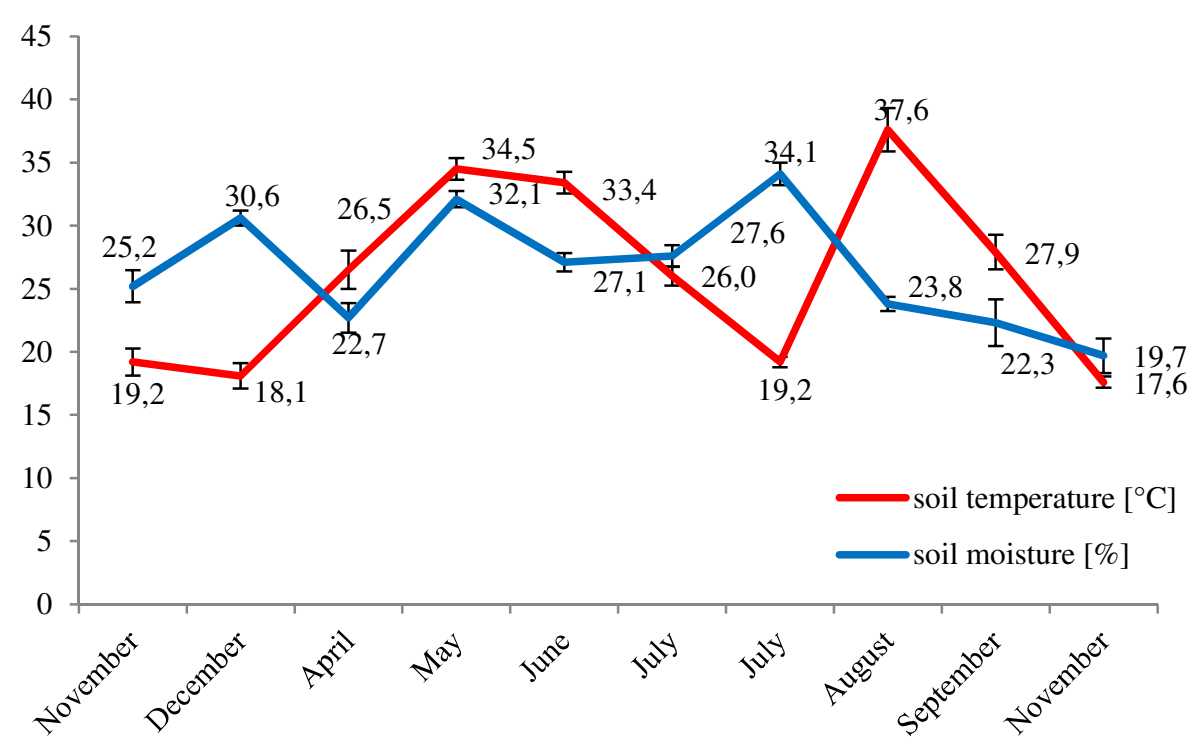

Figure 8. Mean values of soil temperature and soil moisture at $10 \mathrm{~cm}$ depth

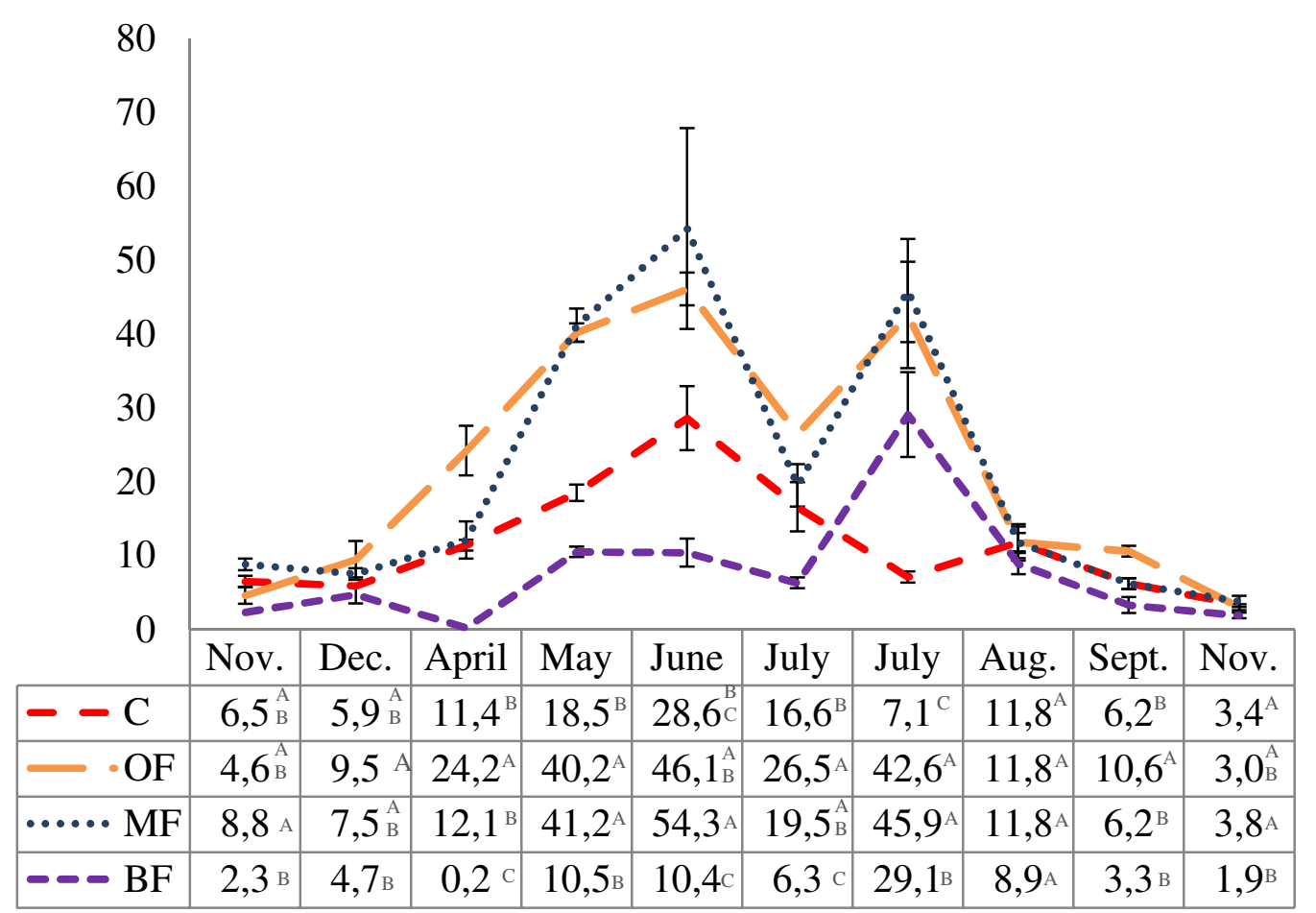

Figure 9. Average daily $\mathrm{C}-\mathrm{CO}_{2}$ flux in $\mathrm{kg} \mathrm{ha}^{-1} \mathrm{day}^{-1}$ according to the treatments [mean values marked with the same letter in the same column are not significantly different $($ SAS 9.1, $p<0.05)]$

Application of $\mathrm{N}$ fertilizer increases plant biomass production, stimulating soil biological activity, and consequently, $\mathrm{CO}_{2}$ emission [44]. Depending on agro-ecological 
factors and fertilization treatments, Figure 9 shows changes in daily flux movement during the year. These results are in accordance with study [45] which stated that the presence of crops on the field affect (increase) $\mathrm{CO}_{2}$ emissions from the soil. In this research, flux at MF treatment was in accordance with study from China [46] where $\mathrm{C}-\mathrm{CO}_{2}$ emissions increased under the influence of $\mathrm{N}$ fertilizer application. The results from study in Iowa show that increasing $\mathrm{N}$ fertilization generally decreased soil $\mathrm{CO}_{2}$ emissions [47]. In this research, average daily $\mathrm{C}-\mathrm{CO}_{2}$ flux varied from $0.2 \mathrm{~kg} \mathrm{ha}^{-1}$ day $^{-1}$ (BF - April) to $54.3 \mathrm{~kg} \mathrm{ha}^{-1} \mathrm{day}^{-1}$ (MF - June) and was significantly different (Figure 9).

Vegetation presence and type are important factors of soil respiration rate. The vegetation presence affects $\mathrm{CO}_{2}$ fluxes primarily by photosynthesizing and by increasing the total ecosystem respiration [48]. Emissions can be higher for $20 \%$ in the soils with crop presence compared to black fallow [49]. Accordingly, during the investigated year the vegetation peak is clearly visible in Figure 9 due to the presence of vegetation in $\mathrm{C}, \mathrm{OF}$ and $\mathrm{MF}$ treatments. Even in $\mathrm{BF}$ treatment on which vegetation was not present, functional dependence with soil temperature and moisture during the year is clearly visible. Soil respiration is usually the highest in summer, decreases in the colder months and is the lowest in winter [50]. Accordingly, in this research conducted in humid climate region on cultivated land, carbon emissions reached a minimum in November and maximum in June and late July (Figure 9).

\section{Influence of fertilization on soil carbon dioxide emissions and soil properties}

Table 3 shows the average annual $\mathrm{C}-\mathrm{CO}_{2}$ flux values and soil properties depending on the fertilizer treatments. Statistically, significant differences were found between the mean annual $\mathrm{C}-\mathrm{CO}_{2}$ flux in fertilized treatments (OF and MF) compared to the treatment without vegetation $(\mathrm{BF})$ but not with control treatment $(\mathrm{C})$. The highest average annual $\mathrm{C}-\mathrm{CO}_{2}$ flux was determined in $\mathrm{OF}\left(21.9 \mathrm{~kg} \mathrm{ha}^{-1}\right.$ day $\left.^{-1}\right)$ and the lowest on BF (7.8 $\mathrm{kg} \mathrm{ha}^{-1}$ day $^{-1}$ ) (Table 3) which is consistent with results from Nebraska where the average annual $\mathrm{CO}_{2}$ emission of winter wheat ranged from 6.9 to $20.1 \mathrm{~kg} \mathrm{ha}^{-1} \mathrm{day}^{-1}$ [51]. The authors performed a long-term fertilization study of wheat and maize growing season and observed that the highest $\mathrm{C}-\mathrm{CO}_{2}$ flux was found from organic fertilized treatment [51]. Application of fertilizers at a rate of $300 \mathrm{~kg} \mathrm{ha}^{-1} \mathrm{~N}$ per year also increased $\mathrm{C}-\mathrm{CO}_{2}$ emissions [52]. Results from this research observed a significant effect of organic and mineral fertilizer application on some soil properties (Table 2 and Table 3). Mean values of $\mathrm{AP}, \mathrm{AK}, \mathrm{TN}$ and $\mathrm{OM}$ are significantly higher in treatments with fertilization (OF and MF) than on $\mathrm{C}$ and $\mathrm{BF}$ treatments. The mean values of $\mathrm{pH}$ and $\mathrm{EC}$ as well as the total number of fungi between treatments, were not significantly different. The total number of bacteria shows a significant difference between OF and BF treatments.

Table 3. Comparison of mean annual C- $\mathrm{CO}_{2}$ flux and some chemical soil parameters depending on fertilizer treatments [mean values marked with the same letter in the same column are not significantly different (SAS 9.1, $p<0.05)]$

\begin{tabular}{|c|c|c|c|c|c|c|}
\hline Treatment & $\mathrm{C}-\mathrm{CO}_{2}$ flux & OM [\%] & $\mathrm{pH}$ & $\mathrm{EC}\left[\mathrm{mS} \mathrm{m}^{-1}\right]$ & $\mathrm{AP}\left[\mathrm{mg} \mathrm{kg}^{-1}\right]$ & $\mathrm{AK}\left[\mathrm{mg} \mathrm{kg}^{-1}\right]$ \\
\hline $\mathrm{C}$ & $11.6 \mathrm{AB}$ & $1.4 \mathrm{C}$ & $5.9 \mathrm{~A}$ & $10.1 \mathrm{~A}$ & $99 \mathrm{~B}$ & $152 \mathrm{~B}$ \\
\hline $\mathrm{OF}$ & $21.9 \mathrm{~A}$ & $2.8 \mathrm{~A}$ & $5.2 \mathrm{~A}$ & $10.1 \mathrm{~A}$ & $191 \mathrm{~A}$ & $300 \mathrm{~A}$ \\
\hline MF & $21.1 \mathrm{~A}$ & $2.8 \mathrm{~A}$ & $5.2 \mathrm{~A}$ & $10.0 \mathrm{~A}$ & $195 \mathrm{~A}$ & $276 \mathrm{~A}$ \\
\hline $\mathrm{BF}$ & $7.8 \mathrm{~B}$ & $2.2 \mathrm{~B}$ & $5.3 \mathrm{~A}$ & $10.0 \mathrm{~A}$ & $87 \mathrm{~B}$ & $158 \mathrm{~B}$ \\
\hline Treatment & \multicolumn{2}{|c|}{ Total number of bacteria $\left[\times 10^{6} \mathrm{CFU} \mathrm{g}^{-1}\right]$} & \multicolumn{2}{|c|}{ Total number of fungi $\left[\times 10^{4} \mathrm{CFU} \mathrm{g}^{-1}\right]$} & \multicolumn{2}{|c|}{$\mathrm{TN}\left[\mathrm{g} \mathrm{kg}^{-1}\right]$} \\
\hline $\mathrm{C}$ & \multicolumn{2}{|c|}{$13.1 \mathrm{AB}$} & \multicolumn{2}{|c|}{$11.5 \mathrm{~A}$} & \multicolumn{2}{|c|}{$1.1 \mathrm{C}$} \\
\hline $\mathrm{OF}$ & \multicolumn{2}{|c|}{$16.9 \mathrm{~A}$} & \multicolumn{2}{|c|}{$15.9 \mathrm{~A}$} & \multicolumn{2}{|c|}{$1.6 \mathrm{~A}$} \\
\hline MF & \multicolumn{2}{|c|}{$11.2 \mathrm{AB}$} & \multicolumn{2}{|c|}{$15.5 \mathrm{~A}$} & \multicolumn{2}{|c|}{$1.7 \mathrm{~A}$} \\
\hline $\mathrm{BF}$ & \multicolumn{2}{|c|}{$10.0 \mathrm{~B}$} & \multicolumn{2}{|c|}{$12.0 \mathrm{~A}$} & \multicolumn{2}{|c|}{$1.3 \mathrm{~B}$} \\
\hline
\end{tabular}

\section{CONCLUSION}

Climate change is today's biggest challenge. Caused by high levels of GHGs in the atmosphere, as a result of their release from the energy, industry and agriculture sectors, 
it can lead to numerous problems. Agricultural ecosystems play a significant role in GHGs, particularly $\mathrm{CO}_{2}$. Irresponsible land management can lead to increased atmospheric $\mathrm{CO}_{2}$ concentrations that contribute to global warming. Consequently, the aim of this research was to determine the influence of mineral and organic fertilization and agro-ecological factors on $\mathrm{C}-\mathrm{CO}_{2}$ emissions and $\mathrm{C}$ sequestration from agricultural soil. Based on the obtained results, the application of organic and mineral fertilizers proved to be beneficial in terms of average higher yield $(6.4 \times)$, and higher nutrients: $\mathrm{N}(1.7 \times), \mathrm{P}(1.9 \times), \mathrm{K}(1.9 \times)$ and $\mathrm{OM}$ content $(2 \times)$ in the soil compared to the control treatment. Due to higher biomass on OF and MF treatments, larger $\mathrm{C}^{-\mathrm{CO}_{2}}$ emissions occurred $(1.8 \times)$. The highest emission was recorded on OF treatment $\left(21.9 \mathrm{~kg}^{-1}\right.$ ha day $\left.{ }^{-1}\right)$ followed by MF, C and BF treatments. This result is justified because higher yields sequestrated more carbon. $\mathrm{CO}_{2}$ content in agro-ecosystem is balanced because higher yield reduces $\mathrm{C}-\mathrm{CO}_{2}$ emissions through increased photosynthesis. The reduction of $\mathrm{C}-\mathrm{CO}_{2}$ emissions by carbon sequestration is of primary importance as agricultural practice can remove atmospheric carbon by sequestration and thus mitigate climate change by maintaining and increasing the amount of carbon stored in soil and plant material. Based on results obtained by scientific methods and measurements, a basis for further work on sustainable soil management will be created with the same or similar soil use and soil quality, with an emphasis on determining the optimal amount of fertilizer for reducing $\mathrm{CO}_{2}$ emissions from the soil, increasing soil health, $\mathrm{C}$ sequestration, and achieving a satisfactory yield. Also, the future goal includes expanding the research to other GHGs emissions which occurs as the result of anthropogenic activities.

\section{NOMENCLATURE}

$\begin{array}{llc}\text { AK } & \text { available potassium in soil } & {\left[\mathrm{mg} \mathrm{kg}^{-1}\right]} \\ \text { AP } & \text { available phosphorus in soil } & {\left[\mathrm{mg} \mathrm{kg}^{-1}\right]} \\ \mathrm{C}-\mathrm{CO}_{2} & \text { soil flux } & {\left[\mathrm{kg} \mathrm{ha}^{-1} \mathrm{day}^{-1}\right]} \\ \text { EC } & \text { EC measurement value } & {\left[\mathrm{mS} \mathrm{m}^{-1}\right]} \\ \text { OM } & \text { organic matter content in soil } & {[\%]} \\ \text { TN } & \text { soil total nitrogen } & {\left[\mathrm{g} \mathrm{kg}^{-1}\right]}\end{array}$

\section{REFERENCES}

1. Bilandzija, D., Zgorelec, Z., Mesic, M. and Kisic, I., Measurement of Soil $\mathrm{CO}_{2}$ Emissions in Croatia, Proceedings of the Gewex Workshop on the Climate System of the Pannonian Basin, Faculty of Agriculture, University of Osijek, Osijek, Croatia, 2015.

2. Bilandzija, D., Zgorelec, Z. and Kisic, I., The Influence of Agroclimatic Factors on Soil $\mathrm{CO}_{2}$ Emissions, Coll. Antropol., Vol. 38, No.1, pp 77-83, 2014.

3. Bilandzija, D., Zgorelec, Z. and Kisic, I., Influence of Tillage Systems on Short-term Soil $\mathrm{CO}_{2}$ Emissions, Hung. Geo. Bull., Vol. 66, No. 1, pp 29-35, 2017, https://doi.org/10.15201/hungeobull.66.1.3

4. Carlisle, E. A., Steenwerth, K. L. and Smart, D. R., Effects of Land Use on Soil Respiration: Conversion of Oak Woodlands to Vineyard, J. Environ. Qual., Vol. 35, No. 4, pp 1396-1404, 2006, https://doi.org/10.2134/jeq2005.0155

5. Schlesinger, W. H. and Andrews, J. A., Soil Respiration and the Global Carbon Cycle, Biogeochem., Vol. 48, No. 1, pp 7-20, 2000.

6. Duxbury, J. M., The Significance of Agricultural Sources of Greenhouse Gases, Fert. Res., Vol. 38, No. 2, pp 151-163, 1994, https://doi.org/10.1007/BF00748775

7. Norman, J. M., Garcia, R. L. and Verma, S. B., Soil Surface $\mathrm{CO}_{2}$ Fluxes and the Carbon Budget of a Grassland, J. Geophys. Res., Vol. 97, No. 17, pp 18845-18853, 1992, https://doi.org/10.1029/92JD01348

8. Jabro, J. D., Sainju, U., Stevens, W. B. and Evans, R. G., Carbon Dioxide Flux as Affected by Tillage and Irrigation in Soil Converted from Perennial Forages to Annual 
Crops, J. Environ. Manage., Vol. 88, No. 4, pp 1478-1484, 2008, https://doi.org/10.1016/j.jenvman.2007.07.012

9. Lou, Y., Li, Z. and Zhang, T., Carbon Dioxide Flux in a Subtropical Agricultural Soil of China, Water, Air, Soil Poll., Vol. 149, No. 1-4, pp 281-293, 2003, https://doi.org/10.1023/A:1025727504841

10. Mancinelli, R., Marinari, S., Brunetti, P., Radicetti, E. and Campiglia, E., Organic Mulching, Irrigation and Fertilization Affect Soil $\mathrm{CO}_{2}$ Emission and C Storage in Tomato Crop in the Mediterranean Environment, Soil Til. Res., Vol. 152, pp 39-51, 2015, https://doi.org/10.1016/j.still.2015.04.001

11. Al-Kaisi, M. M., Kruse, M. L. and Sawyer, J. E., Effect of Nitrogen Fertilizer Application on Growing Season Soil Carbon Dioxide Emission in a Corn-soybean Rotation, J. Environ. Qual., Vol. 37, No. 2, pp 325-332, 2008, https://doi.org/10.2134/jeq2007.0240

12. Halvorson, A. D., Wienhold, B. J. and Black, A. L., Tillage, Nitrogen, and Cropping System Effects on Soil Carbon Sequestration, Soil Sci. Soc. Am. J., Vol. 66, No. 3, pp 906-912, 2002, https://doi.org/10.2136/sssaj2002.9060

13. Zgorelec, Z., Blazinkov, M., Mesic, M., Bilandzija, D., Percin, A., Sestak, I. and Cacic, M., Soil Management and Climate Change, Project Implementation Report, Faculty of Agriculture, University of Zagreb, Zagreb, Croatia, 2017.

14.Zgorelec, Z., Blazinkov, M., Mesic, M., Bilandzija, D., Percin, A., Sestak, I. and Cacic, M., Soil Management and Climate Change, Project Implementation Report, Faculty of Agriculture, University of Zagreb, Zagreb, Croatia, 2017.

15. Skoric, A., Genesis, Development and Taxonomy of Soil, Ph.D. Thesis, University of Zagreb, Zagreb, Croatia, 1986.

16. Food and Agriculture Organization of the United Nations (FAO), World Reference Base (WRB) for Soil Resources, A Framework for International Classification, Correlation and Communication, Rome, Italy, 2006, http://www.fao.org/3/a-a0510e.pdf, [Accessed: 02-August-2018]

17. HRN ISO11464, Soil Quality - Pre-treatment of Samples for Physico-chemical Analysis, International Organization for Standardization, Geneva, Switzerland, 2004.

18. HRN ISO 10390, Soil Quality - Determination of pH, International Organization for Standardization, Geneva, Switzerland, 2005.

19. HRN ISO 14235, Soil Quality - Determination of Organic Carbon by Sulfochromic Oxidation, International Organization for Standardization, Geneva, Switzerland, 2004.

20. Egner, H., Riehm, H. and Domingo, W. R., Studies on the Chemical Soil Analysis as a Basis for the Assessment of the Nutrient Status of Soils (in German), II Chemische Extraktionsmethoden zur Phosphor und Kalium, Vol. 26, pp 45-61, 1960.

21. Mesic, M., Percin, A., Bogunovic, I., Zgorelec, Z. and Gandjaeva, L., Environmental and Production Aspects of Maize Cultivation in Relation with the Different Time-applied Nitrogen, Columella, Vol. 4, No. 1, pp 181-186, 2017.

22. HRN ISO 13878, Soil Quality - Determination of Total Nitrogen Content by Dry Combustion ("Elemental Analysis"), International Organization for Standardization, Geneva, Switzerland, 2004.

23. HRN ISO 11265, Soil Quality - Determination of the Specific Electrical Conductivity, International Organization for Standardization, Geneva, Switzerland, 2004.

24. Pochon, J., Technical Manual for Soil Microbiology Analysis (in French), Masson, Publications de la Société Linnéenne de Lyon, Paris, France, 1954.

25. Croatian Meteorological and Hydrological Service (DHMZ), http://meteo.hr/index.php, [Accessed: 01-February-2019]

26. Lang, R., Weathering and Soil Formation as an Introduction to Soil Science (in German), Schweizerbart'sche Verlagsbuchhandlung (E. Nagele), Stuttgart, Germany, 1920. 
27. Butorac, A., Department of General Agronomy-practicum, Faculty of Agriculture, University of Zagreb, Zagreb, Croatia, 1988.

28. Walter, H., Harnickell, E. and Mueller-Dombois, D., Climate-diagram Maps of the Individual Continents and the Ecological Climatic Regions of the Earth, Springer-Verlag, Berlin, Germany, 1975, https://doi.org/10.1007/978-3-642-80902-6

29. Thornthwaite, C. W., An Approach Towards a Rational Classification of Climate, Geogr. Rev., Vol. 38, No. 1, pp 55-94, 1948, https://doi.org/10.2307/210739

30. Widen, W. and Lindroth, A., A Calibration System for Soil Carbon Dioxide-efflux Measurement Chambers: Description and Application, Soil Sci. Soc. Am. J., Vol. 67, No. 1, pp 327-334, 2001, https://doi.org/10.2136/sssaj2003.3270

31. Parkin, T. B. and Kaspar, T. C., Temperature Controls on Diurnal Carbon Dioxide Flux: Implications for Estimating Soil Carbon Loss, Soil Sci. Soc. Am. J., Vol. 67, No. 6, pp 1763-1772, 2003, https://doi.org/10.2136/sssaj2003.1763

32. Franzluebbers, K., Franzluebbers, A. J. and Jawson, M. D., Environmental Controls on Soil and Whole-ecosystem Respiration from a Tallgrass Prairie, Soil Sci. Soc. Am. J., Vol. 66, pp 254-262, 2002, https://doi.org/10.2136/sssaj2002.0254

33. Shi, Z., Li, D., Jing, Q., Cai, J., Jiang, D., Cao, W. and Dai, T., Effects of Nitrogen Applications on Soil Nitrogen Balance and Nitrogen Utilization of Winter Wheat in a Rice-wheat Rotation, Field Crop Res., Vol. 127, pp 241-247, 2012, https://doi.org/10.1016/j.fcr.2011.11.025

34. Pan, J., Zhu, Y., Jiang, D., Dai, T., Li, Y. and Cao, W., Modelling Plant Nitrogen Uptake and Grain Nitrogen Accumulation in Wheat, Field Crops Res., Vol. 97, No. 2, pp 322-336, 2006, https://doi.org/10.1016/j.fcr.2005.11.006

35. Buranova, S., Cerny, J., Mitura, K. and Lipinska, K. J., Effect of Organic and Mineral Fertilizers on Yield Parameters and Quality of Wheat Grain, Plant Sci., Vol. 47, No. 2, pp 47-53, 2016, https://doi.org/10.1515/sab-2016-0008

36. Vogtmann, H., Matthies, K., Kehres, B. and Meier-Ploeger, A., Enhanced Food Quality: Effects of Compost on the Quality of Plant Foods, Compost Sci. Util., Vol. 1, No. 1, pp 82-100, 1993, https://doi.org/10.1080/1065657X.1993.10771129

37. Grayston, S. J., Wang, S., Campbell, C. D. and Edwards, A. C., Selective Influence of Plant Species on Microbial Diversity in the Rhizosphere, Soil Biol. Biochem., Vol. 30, No. 3, pp 369-378, 1998, https://doi.org/10.1016/S0038-0717(97)00124-7

38. Nannipieri, P., Ascher, J., Ceccherini, M. T., Landi, L., Pietramellara, G. and Renella, G., Microbial Diversity and Soil Functions, Eur. J. Soil Sci., Vol. 54, No. 4, pp 655-670, 2003, https://doi.org/10.1046/j.1351-0754.2003.0556.x

39. Zhong, W., Gu, T., Wang, W., Zhang, B., Lin, X., Huang, Q. and Shen, W., The Effects of Mineral Fertilizer and Organic Manure on Soil Microbial Community and Diversity, Plant Soil, Vol. 326, No. 1-2, pp 511-522, 2010, https://doi.org/10.1007/s11104-009-9988-y

40. Moore, T. R. and Dalva, M., Methane and Carbon Dioxide Exchange Potentials of Peat Soils in Aerobic and Anaerobic Laboratory Incubations, Soil Biol. Biochem., Vol. 29, No. 8, pp 1157-1164, 1997, https://doi.org/10.1016/S0038-0717(97)00037-0

41. Raich, J. W., Potter, C. S. and Bhagawati, D., Interannual Variability in Global Soil Respiration on a 0.5 Degree Grid Cell Basis (1980-1994), Glob. Chang. Biol., Vol. 8, pp 800-812, 2002, https://doi.org/10.3334/CDIAC/lue.ndp081

42. Raich, J. W. and Schlesinger, W. H., The Global Carbon Dioxide Flux in Soil Respiration and its Relationship to Vegetation and Climate, Tellus, Vol. 44, No. 2, pp 81-99, 1992, https://doi.org/10.1034/j.1600-0889.1992.t01-1-00001.x

43. Grahammer, K., Jawson, M. D. and Skopp, J., Day and Night Soil Respiration from a Grassland, Soil Biol. Biochem., Vol. 23, No. 1, pp 77-81, 1991, https://doi.org/10.1016/0038-0717(91)90165-G 
44. Dick, R. P., A Review: Long Term Effects of Agricultural Systems on Soil Biochemical and Microbial Parameters, Agric. Ecosyst. Environ., Vol. 40, No. 1-4, pp 25-36, 1992, https://doi.org/10.1016/0167-8809(92)90081-L

45. Russell, E. W., Soil Conditions and Plant Growth (10 ${ }^{\text {th }}$ ed.), Longmans, London, UK, pp 403-405, 1973.

46. Iqbal, J., Hu, R. G., Lin, S., Hatano, R. and Feng, M. L., $\mathrm{CO}_{2}$ Emission in a Subtropical Red Paddy Soil (Ultisol) as Affected by Straw and N Fertilizer Applications: A Case Study in Southern China, Agric. Ecosyst. Environ., Vol. 131, No. 3-4, pp 292-302, 2009, https://doi.org/10.1016/j.agee.2009.02.001

47. Wilson, H. M. and Al-Kaisi, M. M., Crop Rotation and Nitrogen Fertilization Effect on Soil $\mathrm{CO}_{2}$ Emissions in Central Iowa, App. Soil Ecol., Vol. 39, No. 3, pp 264-270, 2008, https://doi.org/10.1016/j.apsoil.2007.12.013

48. Han, G. X., Yang, L. Q., Yu, J. B., Wang, G. M., Mao, P. L. and Gao, Y. J., Environmental Controls on Net Ecosystem $\mathrm{CO}_{2}$ Exchange Over a Reed (Phragmites Australis) Wetland in the Yellow River Delta, China, Estuar. Coasts, Vol. 36, No. 2, pp 1-3, 2012, https://doi.org/10.1007/s12237-012-9572-1

49. Raich, J. W. and Tufekcioglu, A., Vegetation and Soil Respiration: Correlations and Controls, Biogeochem., Vol. 48, No. 1, pp 71-90, 2000, https://doi.org/10.1023/A:1006112000616

50. Bilandzija, D., Zgorelec, Z. and Kisic, I., Influence of Tillage Practices and Crop Type on Soil $\mathrm{CO}_{2}$ Emissions, Sustainability, Vol. 8, No. 1, pp 90, 2016, https://doi.org/10.3390/su8010090

51. Kessavalou, A., Mosier, A. R., Doran, J. W., Drijber, R. A., Lyon, D. J. and Heinemeyer, O., Fluxes of Carbon Dioxide, Nitrous Oxide, and Methane in Grass Sod and Winter Wheat-Fallow Tillage Management, J. Environ. Qual., Vol. 27, No. 5, pp 1094-1104, 1998, https://doi.org/10.2134/jeq1998.00472425002700050015x

52. Ding, W. X., Meng, L., Yin, Y. F., Cai, Z. C. and Zheng, X. H., $\mathrm{CO}_{2}$ Emission in an Intensively Cultivated Loam as Affected by Long-term Application of Organic Manure and Nitrogen Fertilizer, Soil Biol. Biochem., Vol. 39, No. 2, pp 669-679, 2007, https://doi.org/10.1016/j.soilbio.2006.09.024, 